\title{
Helena Synowiec*
}

iD https://orcid.org/0000-0002-7220-4673

\section{O funkcjonalności wiedzy o języku w szkole (na tle tradycji dydaktycznej)}

Do podjęcia problemu funkcjonalności wiedzy o języku w szkole - wielokrotnie już omawianego przez językoznawców i dydaktyków ${ }^{1}$ - skłaniają mnie dokonujące się obecnie przeobrażenia w edukacji. W nowych „Podstawach programowych języka polskiego” (2016 r.) można bowiem zauważyć zwrot w stronę tradycji uczenia w szkole o systemie językowym, zaznaczający się formalnie w wyodrębnieniu działu "Gramatyka języka polskiego"2. W związku w tym powracają istotne dla

* Prof. dr hab., Uniwersytet Śląski w Katowicach, Wydział Filologiczny, Katedra Dydaktyki Języka i Literatury Polskiej, pl. Sejmu Śl. 1, 43-032 Katowice, helena.syn@wp.pl

1 Por. m.in. M. Dudzik, Korelacja ćwiczeń w mówieniu i pisaniu z nauką o języku (szkic koncepcji programu), w:Kształceniejęzykowewszkole, red. M. Dudzik, Wydawnictwo UWr, Wrocław 1981, t. 1, s. 67-108; por. też artykuły tej autorki w tomach 6-10 serii Kształcenie językowe w szkole; B. Niesporek, K. Orłowa, H. Synowiec, O funkcjonalne nauczanie gramatyki (z badań nad procesem dydaktycznym w zakresie nauki ojęzyku), w: Z Teorii i Praktyki Dydaktycznej Języka Polskiego, t. 11, red. E. Polański, Wydawnictwo UŚ, Katowice 1991, s. 51-64; R. Pawłowska, Siatka podstawowych pojęć kształcenia językowego w szkole, w: W kręgu zagadnień dydaktyki języka i literatury polskiej, pod red. H. Synowiec, Wydawnictwo UŚ, Katowice 2002, s. 47-56; taż: Przygotowanie nauczyciela do kształcenia językowego uczniów, w: Wiedza o języku i kompetencje językowe uczniów, red. B. Niesporek-Szamburska, Wydawnictwo UŚ, Katowice 2012, s. 119-128; J. Porayski-Pomsta, Kształcenie językowe w zreformowanej szkole, w: Horyzonty edukacji językowej, literackiej i kulturowej, red. R. Mrózek, Wydawnictwo UŚ, Cieszyn 2003, s. 33-40; J. Puzynina, Nauka o języku w szkole XXI wieku, w: Horyzonty edukacji językowej, literackiej i kulturowej, red. R. Mrózek, Wydawnictwo UŚ, Cieszyn 2003, s. 13-19; J. Kowalikowa, H. Synowiec, Miejsce nauki o języku w kształceniu językowym uczniów, w: Kształcenie sprawności językowej i komunikacyjnej. Obraz badań i działań dydaktycznych, red. Z. Uryga i M. Sienko, Wydawnictwo Naukowe Akademii Pedagogicznej, Kraków 2005, s. 45-56; J. Kowalikowa, Świadomość językowa w aspekcie edukacyjnym przekładana na działania dydaktyczne, w: Język a Edukacja, t. 3; Świadomość Językowa, red. J. Nocoń,

A. Tabisz, Wydawnictwo UO, Opole 2014, s. 25-36.

2 W artykule nie analizuję treści tego dokumentu ministerialnego. Wiele szczegółowych uwag o nim znalazło się w opinii przygotowanej przez Zespół Dydaktyczny Rady Języka Polskiego, 
praktyki dydaktycznej pytania: jak uczyć, by szkolna wiedza o języku („gramatyka") zyskała wymiar funkcjonalny, a także jak przygotować studentów - przyszłych nauczycieli do wprowadzania tej wiedzy w szkole z uwzględnieniem zarówno potrzeb językowych młodzieży, jak i współczesnych uwarunkowań kulturowo-cywilizacyjnych. Przypomnijmy, że funkcjonalny to - zgodnie z definicją słownikową - taki, który ma związek z funkcjonowaniem i przeznaczeniem czegoś; dobrze spełniający swoją funkcję ${ }^{3}$. Wykładnikami funkcjonalności tzw. wiedzy wyraźnej o języku (tzn. wiedzy nieintuicyjnej, uświadamianej przez użytkowników) są takie koncepcje nauczania, w których podporządkowuje się tę wiedzę nauce języka; traktuje się język jako narzędzie komunikacji i tworzywo tekstów, docenia się praktyczne umiejętności uczniów. Praktyczne działania językowe oraz ich wytwory (teksty mówione i pisane) są przedmiotem obserwacji i analizy, prowadzącej do poznawania przez dzieci zjawisk z poszczególnych podsystemów języka oraz świadomego poprawnego posługiwania się językiem.

Warto sięgnąć najpierw do tradycji dydaktycznej szkolnej nauki o języku ojczystym z lat międzywojennych (a nawet wcześniejszych) ${ }^{4}$ i przywołać prekursorską publikację z tego zakresu - „Dydaktykę nauki o języku ojczystym” Zenona Klemensiewicza, wydaną w 1929 roku $^{5}$. Już wówczas autor domagał się należnego miejsca dla języka polskiego w szkole, wskazywał na znaczenie, jakie ma jego poznawanie dla rozwoju osobowości uczniów. Harmonijnie łączył cel teoretyczno-poznawczy z kształcąco-normatywnym, a strukturalny opis języka wiązał z etapami procesu myślenia dzieci i młodzieży. W założeniach Klemensiewiczowskiej dydaktyki nauki o języku wyraźnie przejawiał się antropocentryzm: wiedza językowa stanowi cząstkę wiedzy o człowieku (wszak to właśnie język jest narzędziem wyrażania myśli i uczuć); głębsze rozumienie nauczania języka i jego funkcji de-

w którego pracach uczestniczę. Nadmienię tylko, że nazwę "Gramatyka języka polskiego" użytą w nagłówku segmentu „Podstawy programowej języka polskiego” uważam za niefortunną, gdyż budzi skojarzenia z „suchą” (encyklopedyczną) wiedzą o systemie, pośrednio sygnalizuje powrót do formalizmu dydaktycznego w kształceniu językowym, a ponadto - nazwa ta nie do końca jest przystawalna do treści kształcenia, które zapowiada.

3 Por. Inny słownik języka polskiego, red. M. Bańko, t. 1, Wydawnictwo Naukowe PWN, Warszawa 2000, s. 424; Stownik współczesnego języka polskiego, red. B. Dunaj, Wydawnictwo Wilga, Warszawa 1996; por. też definicję wyrazu funkcja 'rola pełniona przez coś, zadanie czegoś [...]', tamże, s. 262-263.

4 Poglądy językoznawców (m.in. Jana Baudouina de Courtenay, Jana Łosia, Stanisława Szobera) na cele i zadania nauki o języku relacjonuje - odwołując się do pracy Prądy w nauczaniu języka polskiego, Warszawa 1908 - Michał Jaworski w Metodyce nauki o języku polskim, Państwowe Wydawnictwo Naukowe, Warszawa 1978.

5 Z. Klemensiewicz, Dydaktyka nauki o języku ojczystym. Zasady i zagadnienia, Książnica-Atlas, Lwów-Warszawa 1929; por. też wcześniejszą publikację tego autora pt. Metodyka nauczania głosowni opisowej w gimnazjum, Książnica-Atlas, Lwów-Warszawa 1926. 
cyduje o wszechstronnym rozwoju ucznia i możliwościach uczenia się 6 Z. Klemensiewicz zaznaczał jednak, iż w szkole nie powinno się przekazywać dzieciom „katalogu szczegółów gramatycznych”, wprost przeciwnie - trzeba odchodzić od reprodukowania wiadomości gramatycznych na rzecz wiedzy, ułatwiającej dzieciom porozumiewanie się z innymi, odpowiedzialne uczestniczenie w życiu społecznym oraz świadomy odbiór dzieł literackich ${ }^{7}$. Autor pisał:

Chcemy, żeby uczeń posiadł dobrą znajomość języka współczesnego wspartą podstawowymi [podkr. H. S.] wiadomościami o rozwoju języka ojczystego i o języku w ogóle, żeby zrozumiał [jego] rolę praktyczną i artystyczną [...]. Chcemy, aby ta wiedza oddziaływała skutecznie na rozwój sprawności językowej w mowie i piśmie. Chcemy, aby nauka języka wywierała możliwie wszechstronny, silny i dodatni wpływ na ogólny rozwój umysłowości ucznia, a także na stosunek ucznia i jego woli do mowy ojczystej $[\ldots]^{8}$.

Z. Klemensiewicz, będąc autorem nowatorskich publikacji metodycznych, cenionym nauczycielem szkoły średniej i wytrawnym dydaktykiem ${ }^{9}$, przywiązywał wagę do czynnej postawy uczniów w poznawaniu języka: dostrzegania przez nich

6 Por. M. Madejowa, Profesor Zenon Klemensiewicz na nowo odczytany, czyli o doświadczalnej dydaktyce nauki o języku ojczystym, w: Wczoraj i dziś edukacji polonistycznej, red. B. Kędzia-Klebeko i A. Ciciak, Wydawnictwo Naukowe US, Szczecin 2001, s. 29-37; Z. Jakubowska, Uczony w służbie szkoły, w: W służbie nauce i szkole. Księga pamiątkowa poświęcona Profesorowi Doktorowi Zenonowi Klemensiewiczowi, red. M. Szymczak, Państwowe Wydawnictwo Naukowe, Warszawa 1970, s. 17-25.

7 Por. M. Madejowa, Profesor Zenon Klemensiewicz na nowo odczytany, czyli o..., por. też: B. Kryda, Nauczyciel jako przewodnik w świecie wartości i literatury - z myśli dydaktycznej Zenona Klemensiewicza, w: Zenon Klemensiewicz (1891-1969). Materiały z sesji naukowej w 20. rocznicę śmierci uczonego, Towarzystwo Literackie im. Adama Mickiewicza, Tarnów 1990.

8 Z. Klemensiewicz, Dydaktyka nauki..., s. 70.

9 Profesor Zenon Klemensiewicz w latach 1919-1939 uczył w Gimnazjum Króla Jana III Sobieskiego w Krakowie, gdzie wcześniej (w 1915 r.) odbywał praktykę nauczycielską (wówczas było to gimnazjum męskie), a podczas II wojny światowej uczył na tajnych kompletach licealnych. Od 1923 r. wykładał dydaktykę języka polskiego w Studium Pedagogicznym UJ i w Instytucie Pedagogicznym w Katowicach. Jego pierwsze prace dydaktyczne były drukowane w 1922 r. pod znamiennymi tytułami Dwa urywki z dziennika polonisty i Jak uczyć języka ojczystego. W drugim z wymienionych artykułów wytyczył sobie cel stworzenia metodyki nauczania gramatyki i opracowania nowych dobrych podręczników, por. szerzej I. Bajerowa, Kim był Zenon Klemensiewicz, w: Zenon Klemensiewicz (1891-1969), Materiały z sesji naukowej w 20. rocznicę śmierci uczonego, Towarzystwo Literackie im. Adama Mickiewicza, Tarnów 1990, s. 12. Fragmenty dziennika praktyki nauczycielskiej zostały opublikowane w książce pt. Profesor Zenon Klemensiewicz. Wielki miara w swojej skromności i pracowitości, red. A. Wnętrzak, Wydawnictwo Jubileuszowe Zespołu Szkół Poligraficzno-Księgarskich im. Zenona Klemensiewicza, Kraków 2003, s. 74-76. 
form językowych, wyrazów i wyrażeń, obserwowania, opisywania i analizowania tychże form, uogólniania i wnioskowania ${ }^{10}$. Doceniając rolę indukcji w nauczaniu, zwracał uwagę na wybór materiału przykładowego, który miał być przedmiotem obserwacji i opisu, a także na sposoby jego gromadzenia (m.in. sięgania do różnych tekstów i doświadczeń językowych uczniów), przede wszystkim zaś na rozbudzanie zainteresowań zagadnieniami językowymi i związaną z tym motywację dzieci do ich poznawania"1. Wiele uwagi poświęcał też takiemu ukierunkowywaniu działań uczniów, które sprzyjałoby rozwojowi ich myślenia i spostrzegawczości oraz odkrywaniu przez nich istotnych cech wyrazów i form językowych (ich znaczenia, budowy i funkcji), werbalizowaniu spostrzeżeń, tworzeniu wypowiedzi poprawnych (tj. praktycznemu opanowaniu norm językowych). Dydaktyczne założenia funkcjonalnego ujmowania wiedzy o języku w szkole - skonkretyzowane przez Klemensiewicza w jego podręcznikach ${ }^{12}$ i prelekcjach dla nauczycieli - wyrastały nie tylko z jego wysokich kompetencji językoznawczych, ale również z dogłębnej wiedzy psychologicznej i pedagogicznej. Ponadto zostały wsparte jego badaniami

10 Studenci hospitujący prowadzone przez niego lekcje podkreślali, że czynił to po mistrzowsku, por. wypowiedzi Haliny Skalskiej i Urszuli Wińskiej zamieszczone w: W służbie nauce i szkole. Księga pamiątkowa poświęcona Profesorowi Doktorowi Zenonowi Klemensiewiczowi, komitet red. W. Krencik (i in.), Państwowe Wydawnictwo Naukowe, Warszawa 1970, s. 45-96, 55-56.

11 Por. Z. Klemensiewicz, Wybrane zagadnienia metodyczne z zakresu nauczania gramatyki, Państwowe Zakłady Wydawnictw Szkolnych, Warszawa 1959; tenże: Sposoby wprowadzania, opracowania i utrwalania nowego materiału, w: Wybór prac z metodyki nauczania języka polskiego, pod red. B. Wieczorkiewicza, Państwowe Zakłady Wydawnictw Szkolnych. Warszawa 1968; por. też artykuły na temat dydaktycznych dokonań Z. Klemensiewicza: Z. Jakubowska, Uczony..., s. 17-25; taż, O działalności dydaktycznej profesora Zenona Klemensiewicza, „Język Polski” 1961, nr 5; M. Madejowa, Profesor Zenon Klemensiewicz na nowo odczytany w świetle wspótczesnej reformy oświaty, w: Profesor Zenon Klemensiewicz, Wielki miarq w swojej skromności i pracowitości, red. A. Wnętrzak, Wydawnictwo Jubileuszowe Zespołu Szkół Poligraficzno-Księgarskich im. Znona Klemensiewicza, Kraków 2003, s. 46-51; por. także M. Szymańska, Między naukq o języku a rozwijaniem języka. Koncepcje kształcenia językowego na przełomie XX i XXI wieku, Wydawnictwo Naukowe UP, Kraków 2016, s. 40-50.

12 Z. Klemensiewicz był pierwszym autorem systematycznie opracowanych w latach 1926-1937 kilku podręczników języka polskiego dla uczniów wyższych klas szkoły powszechnej i gimnazjum; korzystali z nich również uczniowie uczęszczający w czasie okupacji na tajne komplety. Podczas wojny jego podręczniki ukazywały się za granicą (np. w 1943 r. - podręcznik dla kl. V wydano w Londynie, w 1945 r. - w Hamburgu), niektóre wznawiano w Bari we Włoszech, a uczyły się z nich dzieci żołnierzy Armii Polskiej na Wschodzie, por. K. Pisarkowa, Patron Zenon Klemensiewicz, w: Profesor Zenon Klemensiewicz. Wielki miara w swojej skromności i pracowitości, red. A. Wnętrzak, Wydawnictwo Jubileuszowe Zespołu Szkół Poligraficzno-Księgarskich im. Zenona Klemensiewicza, Kraków 2003, s. 44, Po II wojnie Z. Klemensiewicz wespół z Janiną Żlabową przystosował treści podręczników do nowych programów nauczania i funkcjonowały one w szkołach w latach 50.-60. XX wieku. 
porównawczymi dotyczącymi nauczania języka ojczystego w różnych krajach Europy $^{13}$. Dodajmy, że autor „Dydaktyki nauki o języku ojczystym” wysuwał postulat opracowania przez językoznawców i dydaktyków we współpracy z nauczycielami tzw. doświadczalnej metodyki nauki o języku polskim dla szkoły podstawowej i gimnazjum. Przez „doświadczalną metodykę" rozumiał taką, która nie opiera się na teorii i intuicji nauczyciela, ale na doświadczeniu i bezpośredniej obserwacji pracy uczniów $w^{14}$. Stale upominał się zarówno o odpowiednią rangę języka ojczystego w szkole, jak i o takie programy nauczania, które będą uwzględniać treści adekwatne do możliwości rozwoju dzieci i młodzieży. Ten postulat pozostaje do dziś aktualny.

Koncepcji funkcjonalnego nauczania o języku, wypracowanej przez Z. Klemensiewicza, nie sposób izolować od jego całościowej wizji kształcenia polonistycznego na poszczególnych poziomach edukacji. Lektura jego artykułów, zwłaszcza szkicu o osobowości nauczyciela ${ }^{15}$, pozwala tę wizję zrekonstruować. Autor wskazywał na integrującą funkcję przedmiotu język polski i kształcone przez nauczycieli ponadprzedmiotowe umiejętności uczniów, a w związku z tym na szczególne zadania polonistów. Akcentował poznawcze i wychowawcze cele kształcenia, aktywną rolę ucznia w procesie nabywania wiedzy oraz odpowiedzialność nauczyciela za dokonywanie wyboru treści z programu nauczania oraz za rozwój wychowanków.

Dydaktyczne poglądy Zenona Klemensiewicza na cele nauki o języku, a także opracowane przez niego sposoby funkcjonalnego ujmowania zagadnień językowych były rozwijane i modyfikowane (w związku z osiągnięciami różnych subdyscyplin językoznawczych, teorii psycholingwistycznych i pedagogicznych) przez kolejne pokolenia dydaktyków oraz językoznawców.

Na uwagę zasługuje tu zwłaszcza stanowisko Jana Tokarskiego ${ }^{16}$. Wskazywał on na konieczność łączenia zagadnień gramatycznych w zwarty system w całym cyklu kształcenia po to, by uczeń zauważał relacje między nimi oraz dostrzegał

13 Badania te Z. Klemensiewicz przeprowadzał w ramach stypendium od grudnia 1926 roku do końca czerwca 1927 roku w takich krajach jak: Austria, Niemcy, Francja, Szwajcaria, Belgia i Czechosłowacja. Na podstawie obserwacji lekcji i analizy programów oraz podręczników, a także po zapoznaniu się z poglądami tamtejszych dydaktyków na nauczanie języka ojczystego przygotował cykl artykułów pt. Nauka gramatyki języka ojczystego za granica, opublikowany na łamach „Języka Polskiego” (1927-1929).

14 Por. Z. Klemensiewicz, Dydaktyka nauki..., s. 18; M. Madejowa, Profesor Zenon Klemensiewicz..., S. 49.

15 Z. Klemensiewicz, Osobowość nauczyciela polonisty, „Pamiętnik Literacki” 1933, z. 2, s. 255-267.

16 Por. J. Tokarski, Gramatyka w szkole. Podstawowe zagadnienia metodyki, Państwowe Zakłady Wydawnictw Szkolnych, Warszawa 1966; tenże, Nauczanie gramatyki, w: Metodyka nauczania języka polskiego w klasach V-VIII szkoły podstawowej, red. M. Pęcherski, Państwowe Zakłady Wydawnictw Szkolnych, Warszawa 1970; por. też tenże, Z pogranicza metodyki i językoznawstwa, Państwowe Zakłady Wydawnictw Szkolnych, Warszawa 1967. 
możliwości praktycznego zastosowania ${ }^{17}$. Wprowadzanie teorii językowej miało służyć - w założeniach J. Tokarskiego - sprawnemu i poprawnemu wypowiadaniu się oraz usprawnianiu porozumiewania się. Istotną rolę w kształceniu językowym wyznaczał on nie tyle gramatyce normatywnej, ile stylistyce językoznawczej (analizie środków leksykalnych i struktur gramatycznych pod względem ich przydatności w tworzeniu wypowiedzi realizujących różne intencje) ${ }^{18}$. Wiedzę o języku uważał za teoretyczny komponent sprawności językowej, umożliwiający uczniom zorientowanie się $\mathrm{w}$ repertuarze struktur gramatycznych, konstrukcji składniowych i zasobie leksyki, jakimi dysponują; komponent praktyczny natomiast sprowadzał się do umiejętnego spożytkowania językowej podbudowy teoretycznej w konstruowaniu poprawnych wypowiedzi.

Funkcjonalizowanie wiedzy o języku poprzez „przekładanie” jej na praktyczne działania (najczęściej ćwiczenia w mówieniu i pisaniu) ${ }^{19}$ odzwierciedlało się w publikacjach licznego grona dydaktyków w latach 70.-90. XX wieku, najpełniej - w opracowaniach Marii Nagajowej (zwłaszcza w książce „Nauka o języku dla nauki języka” ${ }^{20}$. Autorka uczyniła podstawą swoich dydaktycznych dociekań i propozycji wyniki badań socjolingwistycznych (teorię Basila Bernsteina) oraz osiągnięcia psychologii uczenia się - nauczania. Na budowanie związków między poznawanymi przez uczniów zagadnieniami z zakresu poszczególnych podsystemów języka a umiejętnościami stylistycznymi, komunikacyjnymi i tekstotwórczymi zwracali również uwagę między innymi Anna i Piotr Wierzbiccy, Zygmunt Saloni, Maria Dudzik, Jan Cofalik²1. Komunikacyjne podejście do nauczania ję-

17 J. Tokarski, Gramatyka..., s. 17-20; por. też M. Szymańska, Między nauką..., s. 51-55.

18 J. Tokarski, Gramatyka..., s. 23.

19 Por. J. Bar, Ćwiczenia z zakresu nauki języka oraz nauki o języku - gramatyki w klasach IV-VIII, w: Polonistyka zintegrowana, red. K. Ożóg, J. Pasterska, Wydawnictwo Wyższej Szkoły Pedgogicznej. Rzeszów 2000, s. 161-173.

20 M. Nagajowa, Kształcenie języka ucznia w szkole podstawowej, Wydawnictwa Szkolne i Pedagogiczne, Warszawa 1985; taż, Nauka o języku dla nauki języka, Wydawnictwo ZNP, Kielce 1994; Por. też wcześniejsze opracowanie J. Cofalika i I. Tabakowskiej pt. Kształtowanie języka ucznia w procesie nauczania języka polskiego, Państwowe Zakłady Wydawnictw Szkolnych, Warszawa 1963.

21 Por. A. P. Wierzbiccy, Praktyczna stylistyka, Wiedza Powszechna, Warszawa 1968; P. Wierzbicki, Ćwiczenia stylistyczne, Wydawnictwa Szkolne i Pedagogiczne, Warszawa 1977; A. Wierzbicka, P. Wierzbicki, Kształcenie sprawności językowej, w: Metodyka nauczania języka polskiego w kl. V-VIII, red. M. Pęcherski, Państwowe Zakłady Wydawnictw Szkolnych, Warszawa 1970; M. Dudzik, Korelacja ćwiczeń w mówieniu i pisaniu z nauka o języku w szkole, t. 1., red. M. Dudzik, Wydawnictwo UWr, Wrocław 1981; por. też artykuły tej autorki, publikowane w tomach 6.-9. serii Kształcenie językowe w szkole; jej monografię pt. Kształtowanie kultury wyrażania uczuć i wartości w procesie nauczania języka polskiego, Wydawnictwo UWr, Wrocław 1983 oraz współautorskie opracowanie M. Dudzik, T. Nowakowa, Scenariusze lekcyjne z języka polskiego - przedmiotu edukacji szkolnej, Wydawnictwo UWr, Wrocław 1991; Z. Saloni, O kształceniu 
zyka ojczystego znalazło wyczerpującą konkretyzację w opracowanej przez Annę Dyduchową koncepcji metod kształcenia sprawności językowej. Opanowanie norm językowych (poprawność językową) autorka uznała za niezbędny składnik tej sprawności ${ }^{22}$.

Przeorientowanie hierarchii celów kształcenia językowego w stronę umiejętności komunikacyjnych oraz związane z tym zmiany w dydaktyce języka ojczystego na przełomie XX i XXI wieku (a nawet wcześniej) miały uzasadnienie w obserwacjach i badaniach diagnostycznych nad językiem dzieci i młodzieży (ich zasobem leksykalnym i sprawnością językową).Badania te ujawniły m. in. słabą „mowność” uczniów, nieumiejętność operowania słownictwem, „sztywność” wypowiedzi uczniowskich. Przyczyn tego stanu upatrywano w czynnikach dydaktycznych: niewłaściwej organizacji uczenia (się) - nauczania, werbalnej dominacji nauczyciela na lekcji (przekazywanie encyklopedycznej wiedzy o języku bez jej powiązania z praktyką i sytuacjami porozumiewania się). W związku z tym dydaktycy języka ojczystego - nawiązując do osiągnięć subdyscyplin językoznawstwa (nie tylko socjolingwistyki, ale też pragmalingwistyki, teorii tekstu oraz antropocentrycznych teorii lingwistycznych, np. językowego obrazu świata), a także do doświadczeń glottodydaktyków - poszukiwali skutecznych form kształcenia językowego ${ }^{23}$. Ich poszukiwania zaowocowały nowymi koncepcjami w tej dziedzinie, które zostały skonkretyzowane w programach nauczania (a później w podstawach programowych i tzw. programach autorskich). Dowartościowano w nich komunikacyjny i tekstotwórczy aspekt języka. Prekursorskie były pod tym względem podręczniki serii „To lubię” autorstwa zespołu dydaktyków krakowskiej Wyższej Szkoły Pedagogicznej (później Uniwersytetu Pedagogicznego), a ponadto opracowana w tym zespole „Sztuka pisania”24. Usystematyzowana wiedza o strukturze języka w samym założeniu koncepcji komunikacyjnej zeszła na plan dalszy, na pierwszym planie znalazło się wychowanie językowe. Pojęcia gramatyczne wprowadzano

umiejętności pisania, Wydawnictwa Szkolne i Pedagogiczne, Warszawa 1979; J. Cofalik, Ćwiczenie precyzji językowej ucznia, Wydawnictwa Szkolne i Pedagogiczne, Warszawa 1978.

22 A. Dyduchowa, Metody kształcenia sprawności językowej: projekt systemu, model podręcznika, Wydawnictwo Naukowe WSP, Kraków 1988; por. też J. Kowalikowa, H. Synowiec, Miejsce nauki o języku..., s. 46-49.

23 Por. H. Wiśniewska, Sprawność językowa i komunikacyjna w historii dydaktyki polonistycznej (1950-2000), w: Kształcenie sprawności językowej i komunikacyjnej. Obraz badań i działań dydaktycznych, red. Z. Uryga i M. Sienko, Wydawnictwo Naukowe Akademii Pedagogicznej, Kraków 2005, s. 29. Autorka zauważyła, że w latach 1990-2000 publikacje dydaktyków (w tomach pokonferencyjnych) rzadko dotyczyły opisów systemu języka, form wypowiedzi i ortografii, częściej natomiast sprawności językowej, rozwijania różnych kompetencji, budowy tekstu.

24 Por. Z.A. Kłakówna, I. Steczko, K. Wiatr, Sztuka pisania. Klasy I-III gimnazjum, Wydawnictwa Edukacyjne, Kraków 2004; Z.A. Kłakówna, K. Wiatr, Nowa sztuka pisania. Klasy IV-VI szkoły podstawowej, Wydawnictwa Edukacyjne, Kraków 2006. 
okazjonalnie, o tyle, o ile wspierały rozwijanie umiejętności zachowań werbalnych $\mathrm{i}$ tworzenia wypowiedzi w różnych sytuacjach porozumiewania się.

Stopniowe „odgramatykalizowanie” kształcenia językowego (po reformie 1999 roku i kolejnej) spowodowało nasilający się kryzys wiedzy o języku ojczystym, obserwowany wśród młodego pokolenia Polaków, osłabiło również motywacje do poznawania standardowej odmiany polszczyzny i respektowania norm poprawności językowej ${ }^{25}$. Równocześnie nowe uwarunkowania cywilizacyjne, dominująca kultura obrazu, moda na tzw. luz obyczajowy oddziaływanie mediów, wywarły (i wywierają) wpływ na język młodzieży i poziom kultury językowego obcowania ${ }^{26}$.

Słabą kompetencję językową ujawniają coraz częściej studenci polonistyki, przygotowujący się do zawodu nauczycielskiego. Wiadomo, że w toku nauki w 3-letnim liceum tylko sporadycznie byli oni zaznajamiani z wiadomościami o języku, nie pozwalał na to bowiem niewielki wymiar godzin wyznaczonych na nauczanie języka polskiego oraz obszerny zakres materiału literacko-kulturowego. Z tej samej przyczyny poloniści nie wprowadzali na tym etapie edukacji ćwiczeń poprawnościowych (zakładano milcząco, że normy gramatyczne i ortograficzne młodzież dobrze opanowała w szkole podstawowej i gimnazjum). Dlatego studentom - przyszłym polonistom brakuje nie tylko kompetencji językowej, ale często także motywacji do poznawania języka. Przed osobami prowadzącymi zajęcia z dydaktyki języka staje więc zadanie przekonania studentów polonistyki, że wiedza o języku - jego budowie, mechanizmach działania i funkcjach jest potrzebna każdemu wykształconemu Polakowi, by mógł świadomie posługiwać się polszczyzną. Budowanie kompetencji wykonawczych (sprawności) bez uwzględnienia tej wiedzy prowadzi często do bezrefleksyjnego pragmatyzmu, a rozwijanie świado-

25 Por. szerzej: H. Synowiec, Język polski w szkole, w: Polszczyzna 200o. Orędzie o stanie języka na przełomie tysiąclecia, red. W. Pisarek, Kraków 1999, s. 115-127; tejże: Kultura języka w polskiej szkole, w: Polszczyzna publiczna początków XXI wieku, red. E. Wolańska, Rada Języka Polskiego przy Prezydium PAN, Warszawa 2007, s. 28-48 oraz O sytuacji języka ojczystego w zreformowanej szkole, w: Kompetencje nauczyciela polonisty we współczesnej szkole, red. E. Bańkowska i A. Mikołajczuk, Wydawnictwo Wydział Polonistyki UW, Warszawa 2006, s. 125-135; por. też J. Porayski-Pomsta, Kształcenie językowe.... Na słabą kompetencję językoznawczą młodzieży zwracali uwagę liczni językoznawcy, m.in. J. Puzynina, M. Karwatowska, M. Bugajski na posiedzeniach Zespołu Dydaktycznego Rady Języka Polskiego, a ich opinie znajdują potwierdzenie w sondażach wiedzy i umiejętności uczniów i studentów różnych kierunków studiów.

26 Młodzi użytkownicy polszczyzny, nieznający norm poprawnościowych lub je ignorujący, są obojętni na sposoby posługiwania się słowem, nie dostrzegają błędów oraz niestosowności wypowiedzeń, a nawet zachowań nieetycznych, por. m.in. K. Ożóg. Polszczyzna przełomu XX i XXI wieku. Wybrane zagadnienia, Wydawnictwo URz, Rzeszów 2001; J. Porayski-Pomsta, Kształcenie językowe..., s. 36; por. też artykuły T. Zgółki, D. Krzyżyk, H. Synowiec w zbiorze pt. Etyka słowa, Wybór opracowań, red. J. Bartmiński, S. Niebrzegowska-Bartmińska, M. Nowosad-Bakalarczyk, J. Puzynina, Lublin 2017, s. 379-384, 392-402. 
mości językowej nie jest możliwe bez zaznajomienia uczniów ze strukturą i funkcjonowaniem systemu języka ${ }^{27}$.

Studenci przygotowujący się do zawodu nauczyciela zazwyczaj postrzegają instrumentalną wartość języka (jako narzędzia porozumiewania się) i jego wartość poznawczą (jako środka wzbogacania wiedzy o świecie), czasem uzmysławiają sobie znaczenie, jakie ma wiedza o języku ojczystym dla uczenia się języków obcych $^{28}$. Nie zdają sobie sprawy z tego, że wypełnianie przez szkołę celów wychowawczych (wychowania młodzieży ku wartościom) ${ }^{29}$ dokonuje się również poprzez język. Przyszłym nauczycielom trzeba zatem wskazywać na wartość języka jako składnika i nośnika kultury, spoiwa narodowego, środka budowania więzi międzyludzkich (też międzypokoleniowych) i dobra samego w sobie ${ }^{30}$.

W przygotowaniu dydaktycznym studentów trzeba zwracać uwagę na różne wymiary funkcjonalności „szkolnej” nauki o języku ${ }^{31}$, zwłaszcza na wymiar integracyjny ${ }^{32}$. Warto przywołać kierunek w lingwistyce, wywodzący się ze strukturalizmu, zwany językoznawstwem funkcjonalnym. Jego reprezentanci, głównie Andre Martinet, traktują język jako system elementów służących realizacji określonego celu. Badając zjawiska językowe, trzeba odkrywać ich celowość, obecną

27 Funkcje wiedzy o języku we współczesnej szkole szczegółowo omawiają językoznawcy i dydaktycy, por. m.in. J. Puzynina, Nauka o języku w szkole XXI wieku, w: Horyzonty edukacji językowej, literackiej i kulturowej, red. R. Mrózek, Wydawnictwo UŚ, Cieszyn 2003, s. 13-19; J. Kowalikowa, O właściwą rangę wiedzy językowej w zreformowanej szkole, w: W kręgu zagadnień dydaktyki języka i literatury polskiej, red. H. Synowiec, Wydawnictwo UŚ, Katowice 2002, s. 39-46; taż, Kształcenie językowe, Teoria dla praktyki, w: Polonista w szkole, Podstawy kształcenia nauczycieli, red. A. Janus-Sitarz, Universitas, Kraków 2004.

28 Por. J. Puzynina, Nauka o języku...; J. Porayski-Pomsta, Kształcenie językowe...; H. Komorowska, Nauczanie języka obcego a interferencja, Wydawnictwa Szkolne i Pedagogiczne, Warszawa 1980.

29 Problem ten podejmują od wielu lat językoznawcy, pedagodzy i dydaktycy, por. m.in. J. Puzynina, O przekazie wartości w nauczaniu języka ojczystego, w: Wartościowanie w dyskursie edukacyjnym, Praca zbiorowa pod red. J. Ożdżyńskiego i S. Śniatkowskiego, Wydawnictwo Akademii Pedagogicznej, Kraków 1999; Edukacja aksjologiczna, t. 1. Wymiary - kierunki - uwarunkowania, red. K. Olbrycht, Katowice 1994; T. Zgółka, Zadania edukacyjne w zakresie kultury języka i etyki w szkole, w: Etyka słowa, Wybór opracowań, red. J. Bartmiński, S. Niebrzegowska-Bartmińska, J. Puzynina, Wydawnictwo UMCS, Lublin 2017, s. 379-384.

30 Por. J. Puzynina, Język wartości, Państwowe Wydawnictwo Naukowe, Warszawa 1992; taż, Nauka o języku....

31 Różne wymiary funkcjonalności omówiono w pracach: J. Kowalikowa, Kształcenie językowe..., s. 117-124; J. Kowalikowa, H. Synowiec, Miejsce nauki o języku..., s. 49-54.

32 Por. Wiązanie kształcenia językowego z literackim w gimnazjach i liceach, pod red. Z. Urygi, R. Jedlińskiego i M. Sienko, Wydawnictwo Naukowe Akademii Pedagogicznej, Kraków 2007; W. Wantuch, Aspekty integracji w nauczaniu języka polskiego, Wydawnictwo Naukowe AP, Kraków 2005; H. Kurczab, Scalanie treści kształcenia w przygotowaniu zawodowym nauczyciela polonisty, Wydawnictwo Wyższej Szkoły Pedagogicznej, Rzeszów 1993. 
we wszystkich płaszczyznach systemu (od fonologii po składnię), ukazywać relacje między elementami poszczególnych podsystemów języka ${ }^{33}$. Mamy tu do czynienia z funkcjonalnością wewnątrzsystemową. W założeniach komunikacyjno-kulturowej i tekstocentrycznej koncepcji kształcenia językowego, wpisanej w obowiązujące do niedawna „Podstawy programowe”, akcentuje się tekstowy i integracyjny wymiar funkcjonalności, zwraca się uwagę na język jako tworzywo tekstów o różnych intencjach i cechach gatunkowych, a uczniów stawia się w roli ich odbiorców i nadawców.

W procesie poznawania języka i jego funkcji trzeba przede wszystkim docenić osobę ucznia; to właśnie on, a nie same zjawiska językowe (np. konstrukcje składniowe czy derywaty słowotwórcze), ma się znaleźć w centrum zainteresowań nauczyciela. Nauczyciel ma go zmotywować i zachęcić do tego, by różne formy językowe w swoich i cudzych wypowiedziach obserwował, próbował opisać, ustalić, jakie mają znaczenie, jak są zbudowane oraz odkryć, do czego są potrzebne, a nawet jakich nastręczają trudności w użyciu.

Studentom przygotowującym się do zawodu nauczycielskiego, nieodzowna jest orientacja w strategiach uczenia (się) o języku i rolach, jakie wyznacza się w nich uczniowi ${ }^{34}$. Uczeń może być bowiem obserwatorem języka, „analitykiem” lub „badaczem" językowych konstrukcji - jeśli nauczyciel wybierze indukcyjny tok poznawczy. Spore korzyści płyną ze strategii, w której stawia się ucznia w roli wykonawcy zadań (np. tworzenia lub celowego przekształcania tekstu) - w ten sposób wiedzę o języku integruje się z rozwijaniem umiejętności komunikacyjnych i tekstotwórczych ${ }^{35}$. Dogłębnej wiedzy językowej wymaga natomiast strategia, w której uczeń ma dokonać oceny tekstów pod względem językowo-stylistycznym. Temu zadaniu - jak sądzę - sprostać by mogli nieliczni studenci filologii polskiej.

Z obserwacji lekcji wynika, że dla nauczycieli (i studentów praktykantów) wyznacznikiem doboru wprowadzanych na lekcjach treści językowych oraz sposobu ich opracowania są przede wszystkim podręczniki szkolne. Spośród proponowa-

33 Por. J. Kowalikowa, Kształcenie językowe..., s. 118-119; por. też, J. Kida, Językoznawstwo funkcjonalne a współczesna koncepcja dydaktyki języka, „Edukacja Humanistyczna” 2000, nr 1, s. 53-63.

34 Przejrzyście i szczegółowo przedstawia ten problem Jolanta Nocoń, egzemplifikując go zadaniami z podręczników szkolnych, por. J. Nocoń, Strategie nabywania wiedzy o języku przez ucznia (na przykładzie zadań podręcznikowych), w: Wiedza o języku i kompetencje językowe uczniów, red. B. Niesporek-Szamburska, Wydawnictwo UŚ, Katowice 2012, s. 27-43.

Por. Wiedza o języku w działaniach twórczych, w: Wiedza o języku i kompetencje językowe uczniów, red. B. Niesporek-Szamburska, Wydawnictwo UŚ, Katowice 2012, s. 359-365; J. Nocoń, Transformacje tekstów w edukacji językowej, w: W kręgu zagadnień dydaktyki języka i literatury polskiej, red. H. Synowiec, Wydawnictwo UŚ, Katowice 2002, s. 171-177; Z. Kłakówna, Sztuka pisania, Ćwiczenia redakcyjne dla klas IV-VI. Metodyczny podręcznik nauczyciela, Wydawnictwo Edukacyjne, Warszawa 1993. 
nych tam modeli kształcenia językowego ${ }^{36}$ na uwagę zasługują - ze względu na funkcjonalizowanie wiedzy językowej - te, w których kształcenie komunikacyjne zostało skorelowane z nauką o języku (choć zakres treści ograniczono tam do doraźnych potrzeb - rozwijania umiejętności mówienia i pisania), a także te, w których opis struktury języka połączono z okazjonalnym kształceniem kompetencji komunikacyjnych: ćwiczenia i zadania uzmysławiają dzieciom związek między wiedzą o systemie a rzeczywistością pozajęzykową. Zasadę funkcjonalności wiedzy o języku respektują ponadto tacy autorzy podręczników, którzy starają się nie tylko łączyć kształcenie umiejętności porozumiewania się z wiedzą o języku, ale jeszcze wzbogacać treści językowe o aspekt kulturowy. Dzięki temu wzajemnie się one przenikają i uzupełniają - uczeń dostrzega relacje między systemem języka a komunikacją werbalną oraz rzeczywistością utrwaloną w tekstach kultury. Funkcjonalizowaniu wiedzy o języku nie sprzyjają natomiast podręczniki, w które wpisany został czysto gramatyczny model kształcenia językowego, z dominującym celem teoretyczno-poznawczym. Występują w nich pojęcia i terminy (objaśnione albo opisowo, albo z przytoczeniem definicji) oraz ćwiczenia, polegające na analizowaniu elementów systemu językowego (np. rozpoznawanie form gramatycznych, wypisywanie z tekstów części mowy) lub też na poprawnym używaniu trudniejszych konstrukcji składniowych i wyrazów w kontekście zdania. Podręczniki tego typu zawierają uporządkowane wiadomości o systemie (podsystemach językowych) polszczyzny, nie uzmysławiają jednak użyteczności omawianych składników języka w codziennej komunikacji, w tworzeniu wypowiedzi, w osiąganiu pożądanych cech tekstu (np. zwięzłości, ekspresywności, plastyczności).

Refleksji krytycznej warto poddać również poradniki dla nauczycieli (dawne i aktualne), zwłaszcza zaś proponowane - także w wersji elektronicznej - rozwiązania metodyczne (konspekty i projekty lekcji). Nie zawsze są one podbudowane teoretycznie (językoznawczo, psychodydaktycznie), a bywa, że upowszechnia się w nich wzorce nieakceptowalne ze względów merytorycznych i będące zaprzeczeniem funkcjonalności wiedzy językowej.

Studenci i młodzi nauczyciele „podpatrują” warsztat polonistyczny i starają się twórczo wykorzystać cudze propozycje dydaktyczne. Zazwyczaj jednak - jak

36 Modele te - na podstawie analizy podręczników kształcenia językowego kl. IV-VI szkoły podstawowej i klas gimnazjalnych - wyodrębnił i opisał Piotr Zbróg. Dokonał również ich oceny, przyjmując następujące kryteria: umożliwienia zdobycia wiedzy o systemie języka, stopień wspomagania przez wiedzę o języku wiedzy o komunikacji językowej, opanowanie umiejętności komunikacyjnych. Por. P. Zbróg, Modele kształcenia językowego w podręcznikach do języka polskiego a potrzeby komunikacyjne uczniów, w: Podręczniki do kształcenia polonistycznego w zreformowanej szkole - koncepcje, funkcje, język, red. H. Synowiec, Wydawnictwo Edukacyjne, Kraków 2006, s. 29-42; por. też M. Karwatowska, L. Tymiakin, Funkcjonowanie wiedzy lingwistycznej w podręcznikach do kształcenia językowego dla gimnazjum, w: Podręczniki do kształcenia językowego w zreformowanej szkole..., s. 260-278. 
wynika z obserwacji praktyki - nie biorą pod uwagę realiów kulturowo-językowych środowiska, w którym pracują, np. swoistych uwarunkowań kształcenia językowego uczniów mieszkających na zwartych terenach dialektalnych (np. na Śląsku, Podhalu, Kurpiach) i na terenach wiejskich pozostałych regionów ${ }^{37}$. W tamtejszych szkołach zachodzi potrzeba rozwijania tzw. podwójnej kompetencji językowej uczniów i zapobiegania interferencjom gwarowym w wypowiedziach oficjalnych ${ }^{38}$. Zasadę funkcjonalności wiedzy o języku powinno się tam uwzględnić, ucząc o odmianach terytorialnych polszczyzny: zaplanować elementy praktycznej wiedzy o gwarze regionu oraz ćwiczenia i działania, które pomogą uzmysłowić dzieciom podobieństwa i różnice między formami gramatycznymi i wyrazami w polszczyźnie standardowej i rodzimej dla nich gwarze, a także pozwolą zorientować się w zakresie i zasięgu społecznej używalności gwary (ograniczonym do lokalnych, regionalnych i rodzinnych kontaktów). Chodzi przy tym z jednej strony o zmotywowanie uczniów do dobrego opanowania języka ogólnopolskiego (służącego komunikacji ponadregionalnej), a z drugiej - do pielęgnowania odmiany dialektalnej jako swoistego bogactwa kulturowego, kulturotwórczego i wspólnototwórczego ${ }^{39}$. Przeszkodę w funkcjonalnym uczeniu o języku w środowiskach gwarowych stanowi bardzo słabe przygotowanie polonistów w dziedzinie dialektologii i etnolingwistyki - w ostatnich latach bowiem w większości uczelni wycofano z siatek studiów polonistycznych dialektologię, a więc jedynie w ramach zajęć z dydaktyki języka wyposaża się studentów w podstawową wiedzę o gwarach oraz wykazuje się jej przydatność w edukacji ${ }^{40}$.

W kształceniu kompetencji metodycznych przyszłych nauczycieli dydaktycy napotykają spore trudności, wynikające ze wspomnianego już niedostatecznego językowego i językoznawczego przygotowania, które studenci filologii polskiej wy-

37 Por. Odmiany polszczyzny w szkole, pod red. H. Synowiec przy współpracy M. Kubarek, Wydawnictwo UŚ, Katowice 2013.

38 O kształceniu podwójnej kompetencji językowej uczniów ze środowisk gwarowych por. m.in.

B. Cząstka-Szymon, H. Synowiec, Polszczyzna w szkole śląskiej, cz. I i II, Wydawnictwo „Śląsk”, Katowice 1996; H. Synowiec, Śląska ojczyzna polszczyzna z perspektywy edukacyjnej, Wybrane zagadnienia, Wydawnictwo Sapientia, Katowice 2013, s. 94-122; taż, Zróżnicowanie terytorialne polszczyzny a edukacja językowa, w: Odmiany polszczyzny w szkole, red. H. Synowiec przy współpracy M. Kubarek, Wydawnictwo UŚ, Katowice 2013, s. 50-65.

39 O docenieniu wartości gwary oraz jej funkcji kulturotwórczej w edukacji por. szerzej H. Synowiec, Śląska ojczyzna polszczyzna..., s. 141-179, 207-220.

40 Warto w tym miejscu upomnieć się o przywrócenie dialektologii jako przedmiotu obligatoryjnego na kierunkach filologii polskiej (specjalności nauczycielskiej) i pedagogiki wczesnoszkolnej. Znaczenie tego przedmiotu dla dydaktyki szkolnej podkreślają od dawna liczni językoznawcy, m.in. H. Kurek, S. Gala, U. Żydek-Bednarczuk, J. Kowalik, R. Mrózek, por. Teoretyczne, badawcze i dydaktyczne założenia dialektologii, red. S. Gala, Wydawnictwo Łódzkie Towarzystwo Naukowe, Łódź 1998; H. Synowiec, Zróżnicowanie.... 
nieśli z edukacji szkolnej. Stan świadomości językowej wielu absolwentów liceów jest zatrważający: nie znają oni podstawowych pojęć i terminów gramatycznych, dysponują intuicyjną, fragmentaryczną i niezoperatywizowaną wiedzą z gramatyki i kultury języka polskiego, nie opanowali praktycznie reguł ortograficznych i interpunkcji ${ }^{41}$. Tych deficytów młodzi ludzie nie są w stanie samodzielnie uzupełnić podczas studiów. W ramach zajęć z przedmiotów językoznawczych na kierunku filologii polskiej nie zaznajamia się ich bowiem z "tradycyjnym” opisem systemu współczesnego języka polskiego, potrzebnym im w przyszłej pracy szkolnej, ale - co oczywiście jest również niezbędne w wykształceniu akademickim - zapoznaje się ich z nowymi teoriami opisu i metodologiami badań lingwistycznych. Zadanie uzupełnienia wiedzy "gramatycznej” studentów przypada zatem dydaktykom języka, mimo że dysponują na to skromnym limitem czasu. Uzmysławiają oni studentom zależności między zjawiskami z poszczególnych podsystemów językowych (np. fleksją a składnią, składnią a słowotwórstwem), a przede wszystkim wykazują stylistyczną, tekstotwórczą i komunikacyjną funkcję środków językowych, wyjaśniają mechanizmy zamierzonych i niezamierzonych innowacji ${ }^{42}$. Korzystna sytuacja zachodzi wówczas, gdy w siatce studiów zajęcia z dydaktyki języka są zaprogramowane równolegle z przedmiotmi językoznawczymi, ponieważ stwarza to możliwość przetransponowania wiedzy językoznawczej (np. z pragmatyki językowej, kultury języka) w operacje językowe - ćwiczenia i zadania dla ucznia, a równocześnie przekonuje studentów o przydatności teorii językowej dla praktyki dydaktycznej ${ }^{43}$.

Dydaktyk, chcąc przygotować studentów do funkcjonalnego uczenia o języku, często napotyka jeszcze inną przeszkodę. Stanowią ją utrwalone w pamięci studentów stereotypowe obrazy lekcji językowych, w większości prowadzanych metodą wykładu lub pogadanki (podawanie reguł i definicji) bądź ograniczonych do okazjonalnego (intuicyjnego) wykonywania ćwiczeń, rozwiązywania testów, przyswajania wiadomości z podręcznika ${ }^{44}$. Z takich stereotypów niełatwo jest studentów

41 Dostrzegano to już wcześniej, por. artykuły zamieszczone w publikacji zbiorowej Kompetencje nauczyciela polonisty..., Jednakże po kilkunastu latach od ukazania się tej publikacji obserwujemy regres wiedzy i umiejętności językowych absolwentów liceów, spowodowany m.in. czynnikami instytucjonalnymi (nauka w liceum trwała 3 lata) i dydaktycznymi.

42 Na niektórych uczelniach wprowadzono w siatce studiów licencjackich na filologii polskiej konwersatoria z kultury języka (norm językowych) oraz warsztaty z ortografii i interpunkcji.

43 O tym, jaka wiedza językoznawcza i jakie umiejętności opisu lingwistycznego są potrzebne nauczycielowi, szczegółowo pisała m.in. Regina Pawłowska w artykule Jak przygotować nauczyciela polonistę do kształcenia językowego ucznia w pracy zbiorowej Język polski jako przedmiot dydaktyki uniwersyteckiej, pod red. J. Bartmińskiego i M. Karwatowskiej, Wydawnictwo UMCS, Lublin 1998, s. 43-54.

44 Nieliczni studenci mają pozytywne szkolne doświadczenia, dotyczące sposobu uczenia o języku: budzenia zainteresowań, motywowania oraz przystępnego zaznajamiania przez polonistów z zagadnieniami gramatycznymi, wiązania wiedzy z praktycznymi umiejętnościami. 
„wytrącić". Tworzone przez nich pierwsze projekty lekcji zazwyczaj cechują się formalnym podejściem do zjawisk językowych, przekazywaniem „suchej” wiedzy, bezrefleksyjnym powielaniem toku postępowania dydaktycznego, który proponuje autor podręcznika. Dopiero wspólne poszukiwania różnorodnych rozwiązań metodycznych (uzasadnionych etapem rozwoju osobowego ucznia, swoistością środowiska, stopniem trudności materiału językowego) a także projektowanie ćwiczeń gramatyczno-stylistycznych i tekstotwórczych rozbudza w studentach pozytywną motywację do poznawania zagadnień językowych, które wcześniej uważali za zbędny balast. Jeśli na studiach wiedza o współczesnej polszczyźnie będzie wprowadzana funkcjonalnie, skorelowana $\mathrm{z}$ wiedzą o komunikacji językowej $\mathrm{i}$ kulturze, $\mathrm{z}$ uwzględnieniem dorobku różnych dziedzin językoznawstwa, przyszli nauczyciele będą postrzegać język ojczysty jako wartość samą w sobie.

Młodym polonistom trzeba również uzmysławiać tradycję dydaktyczną w zakresie kształcenia językowego, przybliżać wkład językoznawców i dydaktyków $\mathrm{w}$ tworzenie podstaw funkcjonalnej nauki o języku ${ }^{45}$, zaznajamiać ze zmianami, jakie dokonywały się w koncepcji edukacji językowej i skłaniać do refleksji nad konsekwencjami, jakie te zmiany miały (i mają) dla poziomu kompetencji językowej (językoznawczej) uczniów ${ }^{46}$.

\section{Bibliografia}

Bajerowa Irena, Kim był Zenon Klemensiewicz?, w: Zenon Klemensiewicz (1891-1969), Materiały $z$ sesji naukowej $w$ 20. rocznicę śmierci uczonego, Towarzystwo Literackie im. Adama Mickiewicza, Tarnów 1990.

Bar Józef, Ćwiczenia z zakresu nauki jezyka oraz nauki o języku - gramatyki w klasach IV-VIII, w: Polonistyka zintegrowana, red. Kazimierz Ożóg, Jolanta Pasterska, Wydawnictwo Wyższej Szkoły Pedagogicznej, Rzeszów 2000, s. 161-173.

Cofalik Jan, Ćwiczenia precyzji językowej ucznia, Wydawnictwa Szkolne i Pedagogiczne, Warszawa 1978.

45 Por. m.in. K. Gąsiorek, Nauka o języku czyli gramatyka w szkole - wczoraj i dziś, w: Ars Didactica, Księga Jubileuszowa Haliny Zgółkowej, red. K. Czarnecka i M. Grzelka, Wydawnictwo Naukowe UAM, Poznań 2017, s. 75-86; J. Kowalikowa, Wiecznie aktualne problemy dydaktyki języka polskiego, w: D. Krzyżyk, B. Niesporek-Szamburska, Językowe, literackie i kulturowe ścieżki edukacji polonistycznej (tradycja i współczesność), Wydawnictwo UŚ, Katowice 2014, s. 271-290.

46 Por. H. Komorowska, Kształcenie językowe - nowe tendencje w nowym stuleciu, w: Język a Edukacja 1, red. J. Nocoń, B. Skowronek, Wydawnictwo UO, Opole 2012, s. 93-106; J. Nocoń, Uczenie o języku polskim po 1998 - programy i koncepcje dydaktyczne, w: Uczeń w świecie języka i tekstów, red. J. Nocoń, E. Łucka-Zając, Wydawnictwo UO, Opole 2010, s. 27-37. 
Cofalik Jan, Tabakowska Irena, Kształtowanie języka ucznia w procesie nauczania języka polskiego, Państwowe Zakłady Wydawnictw Szkolnych, Warszawa 1963.

Cząstka-Szymon Bożena, Synowiec Helena, Polszczyzna w szkole śląskiej, cz. I i II, Wydawnictwo „Śląsk”, Katowice 1996.

Dudzik Maria, Korelacja ćwiczeń w mówieniu i pisaniu z nauką o języku (szkice koncepcji programu), w: Kształcenie językowe w szkole, red. Maria Dudzik, Wydawnictwo UWr, Wrocław 1981, t. 1, s. 67-108.

Dudzik Maria, Kształcenie kultury wyrażania uczuć i wartości w procesie nauczania języka polskiego, Wydawnictwo UWr, Wrocław 1983.

Dudzik Maria, Nowakowa Teresa, Scenariusze lekcyjne z jezyka polskiego - przedmiotu edukacji szkolnej, Wydawnictwo UWr, Wrocław 1991.

Dyduchowa Anna, Metody kształcenia sprawności językowej: projekt systemu, model podręcznika, Wydawnictwo Wyższej Szkoły Pedagogicznej, Kraków 1988.

Etyka słowa. Wybór opracowań, red. Jerzy Bartmiński, Stanisława Niebrzegowska-Bartmińska, Marta Nowosad-Bakalarczyk, Jadwiga Puzynina, Wydawnictwo UMCS, Lublin 2017.

Gąsiorek Krystyna, Nauka o języku, czyli gramatyka w szkole - wczoraj i dziś, w: Ars Didactica. Księga Jubileuszowa Haliny Zgółkowej, red. Katarzyna Czarnecka, Monika Grzelka, Wydawnictwo Naukowe UAM, Poznań 2017, s. 75-86.

Inny słownik języka polskiego, red. M. Bańko, t. 1, Wydawnictwo Naukowe PWN, Warszawa 2000.

Jakubowska Zofia, Uczony w stużbie szkoły, w: W służbie nauce i szkole. Ksiega pamiątkowa poświęcona Profesorowi Doktorowi Zenonowi Klemensiewiczowi, red. Mieczysław Szymczak, Państwowe Wydawnictwo Naukowe, Warszawa 1970, s. 17-25.

Jaworski Michał, Metodyka nauki o języku polskim, Wydawnictwo Naukowe PWN, Warszawa 1998.

Język a Edukacja, t. 3: Świadomość Językowa, red. Jolanta Nocoń, Anna Tabisz, Wydawnictwo UO, Opole 2014.

Język polski jako przedmiot dydaktyki uniwersyteckiej, red. Jerzy Bartmiński, Małgorzata Karwatowska, Wydawnictwo UMCS, Lublin 1998.

Karwatowska Małgorzata, Tymiakin Leszek, Funkcjonowanie wiedzy lingwistycznej w podręcznikach do kształcenia językowego dla gimnazjum, w: Podręczniki do kształcenia językowego w zreformowanej szkole - koncepcje, funkcje, język, red. Helena Synowiec, Wydawnictwo Edukacyjne, Kraków 2006, s. 60-278.

Kida Jan, Językoznawstwo funkcjonalne a współczesna koncepcja dydaktyki języka, „Edukacja Humanistyczna” 2000, nr 1, s. 53-63.

Klemensiewicz Zenon, Dydaktyka nauki o języku ojczystym. Zasady i zagadnienia, Książnica-Atlas, Lwów-Warszawa 1929.

Klemensiewicz Zenon, Metodyka nauczania głosowni opisowej w gimnazjum, Książnica-Atlas, Lwów-Warszawa 1926. 
Klemensiewicz Zenon, Osobowość nauczyciela polonisty, „Pamiętnik Literacki” 1933, z. 2, s. 255-267.

Klemensiewicz Zenon, Wybrane zagadnienia metodyczne z zakresu nauczania gramatyki, wyd. 2. rozszerzone, Państwowe Zakłady Wydawnictw Szkolnych, Warszawa 1959.

Kłakówna Zofia Agnieszka, Sztuka pisania. Ćwiczenia redakcyjne dla klas IV-VI. Metodyczny podręcznik nauczyciela, Wydawnictwo Edukacyjne, Warszawa 1993.

Kłakówna Zofia Agnieszka, Steczko Iwona, Wiatr Krzysztof, Sztuka pisania. Klasy I-III gimnazjum, Wydawnictwo Edukacyjne, Kraków 2004.

Kłakówna Zofia Agnieszka, Wiatr Krzysztof, Nowa sztuka pisania. Klasy IV-VI szkoły podstawowej, Wydawnictwo Edukacyjne, Kraków 2006.

Komorowska Hanna, Kształcenie językowe - nowe tendencje w nowym stuleciu, w: Język a Edukacja, t. 1., red. Jolanta Nocoń, Bogusław Skowronek, Wydawnictwo UO, Opole 2012, s. 93-106.

Komorowska Hanna, Nauczanie języka obcego a interferencja, Wydawnictwa Szkolne i Pedagogiczne, Warszawa 1980.

Kompetencje nauczyciela polonisty we współczesnej szkole, red. Edyta Bańkowska, Agnieszka Mikołajczuk, Wydawnictwo Wydziału Polonistyki UW, Warszawa 2006.

Kowalikowa Jadwiga, Kształcenie językowe. Teoria dla praktyki, w: Polonista w szkole. Podstawy kształcenia nauczyciela polonisty, red. Anna Janus-Sitarz, Universitas, Kraków 2004.

Kowalikowa Jadwiga, O właściwa range wiedzy językowej w zreformowanej szkole, w: W kręgu zagadnień dydaktyki języka i literatury polskiej, red. Helena Synowiec, Wydawnictwo UŚ, Katowice 2002, s. 39-46.

Kowalikowa Jadwiga, Synowiec Helena, Miejsce nauki o języku w kształceniu językowym uczniów, w: Kształcenie sprawności językowej i komunikacyjnej. Obraz badań i działań dydaktycznych, red. Zenon Uryga, Maria Sienko, Wydawnictwo Naukowe Akademii Pedagogicznej, Kraków 2005, s. 45-56.

Kowalikowa Jadwiga, Wiecznie aktualne problemy dydaktyki języka polskiego, w: Językowe literackie i kulturowe ścieżki edukacji polonistycznej (tradycja i współczesność), red. Danuta Krzyżyk, Bernadeta Niesporek-Szamburska, Wydawnictwo UŚ, Katowice 2014, s. 271-290.

Kryda Barbara, Nauczyciel jako przewodnik w świecie wartości i literatury - z myśli dydaktycznej Zenona Klemensiewicza, w: Zenon Klemensiewicz (1891-1969), Materiały $z$ sesji naukowej $w$ 20. rocznicé śmierci uczonego, Towarzystwo Literackie im. Adama Mickiewicza, Tarnów 1990.

Kształcenie sprawności językowej i komunikacyjnej. Obraz badań i działań dydaktycznych, red. Zenon Uryga, Maria Sienko, Wydawnictwo Naukowe Akademii Pedagogicznej, Kraków 2005.

Kurczab Henryk, Scalanie treści kształcenia w przygotowaniu zawodowym nauczyciela polonisty, Wydawnictwo Wyższej Szkoły Pedagogicznej, Rzeszów 1993. 
Madejowa Maria, Profesor Zenon Klemensiewicz na nowo odczytany, czyli o doświadczalnej dydaktyce nauki o języku ojczystym, w: Wczoraj i dziś edukacji polonistycznej, red. Barbara Kędzia-Klebeka, Anna Ciciak, Wydawnictwo Naukowe US, Szczecin 2001, s. 29-37.

Madejowa Maria, Profesor Zenon Klemensiewicz na nowo odczytany w świetle wspótczesnej reformy oświaty, w: Profesor Zenon Klemensiewicz, Wielki miara w swojej skromności i pracowitości, red. A. Wnętrzak, Wydawnictwo Jubileuszowe Zespołu Szkół Poligraficzno-Księgarskich im. Znona Klemensiewicza, Kraków 2003, s. $46-51$

Nagajowa Maria, Kształcenie języka ucznia w szkole podstawowej, Wydawnictwa Szkolne i Pedagogiczne, Warszawa 1985.

Nagajowa Maria, Nauka o języku dla nauki o języku, Wydawnictwo Związku Nauczycielstwa Polskiego, Kielce 1994.

Niesporek-Szamburska Bernadeta, Orłowa Krystyna, Synowiec Helena, O funkcjonalne nauczanie gramatyki ( $z$ badań nad procesem dydaktycznym $w$ zakresie nauki o języku), w: Z Teorii i Praktyki Dydaktycznej Języka Polskiego, t. 11., red. Edward Polański, Wydawnictwo UŚ, Katowice 1991, s. 51-64.

Nocoń Jolanta, Strategie nabywania wiedzy o języku przez ucznia (na przykładzie zadań podręcznikowych), w: Wiedza o języku i kompetencje językowe uczniów, red. Bernadeta Niesporek-Szamburska, Wydawnictwo UŚ, Katowice 2012, s. 27-43.

Nocoń Jolanta, Transformacje tekstów w edukacji językowej, w: W kręgu zagadnień dydaktyki jezzyka i literatury polskiej, red. Helena Synowiec, Wydawnictwo UŚ, Katowice 2002, s. 171-177.

Nocoń Jolanta, Uczenie o języku polskim po 1998 roku - programy i koncepcje dydaktyczne, w: Uczeń w świecie języka i tekstów, red. Jolanta Nocoń, Elżbieta Łucka-Zając, Wydawnictwo UO, Opole 2010, s. 27-37.

Odmiany polszczyzny w szkole, red. Helena Synowiec przy współpracy Marty Kubarek, Wydawnictwo UŚ, Katowice 2013.

Ożóg Kazimierz, Polszczyzna przełomu XX i XXI wieku. Wybrane zagadnienia, Wydawnictwo URz, Rzeszów 2001.

Pawłowska Regina, Jak przygotować nauczyciela polonistę do kształcenia językowego ucznia, w: Język polski jako przedmiot dydaktyki uniwersyteckiej, red. Jerzy Bartmiński, Małgorzata Karwatowska, Wydawnictwo UMCS, Lublin 1998, s. 43-54.

Pawłowska Regina, Siatka podstawowych pojęć kształcenia językowego w szkole. w: W kręgu zagadnień dydaktyki języka i literatury polskiej, red. Helena Synowiec, Wydawnictwo UŚ, Katowice 2002, s. 47-56.

Porayski-Pomsta Józef, Kształcenie językowe $w$ zreformowanej szkole, w: Horyzonty edukacji językowej, literackiej i kulturowej, red. Robert Mrózek, Wydawnictwo UŚ, Cieszyn 2003, s. 33-40.

Praktyczna stylistyka nie tylko dla polonistów, red. Edyta Bańkowska, Agnieszka Mikołajczuk, Wydawnictwo Wiedza Powszechna, Warszawa 2003. 
Profesor Zenon Klemensiewicz. Wielki miara w swojej skromności i pracowitości, red. Anna Wnętrzak, Wydawnictwo Jubileuszowe Zespołu Szkół Poligraficzno-Księgarskich im. Zenona Klemensiewicza, Kraków 2003, s. 74-76.

Puzynina Jadwiga, Język wartości, Państwowe Wydawnictwo Naukowe, Warszawa 1992. Puzynina Jadwiga, Nauka o języku w szkole XXI wieku, w: Horyzonty edukacji językowej, literackiej i kulturowej, red. Robert Mrózek, Wydawnictwo UŚ, Cieszyn 2003, s. 13-19.

Puzynina Jadwiga, O przekazie wartości w nauczaniu języka ojczystego, w: Wartościowanie $w$ dyskursie edukacyjnym, red. Jan Ożdżyński, Sławomir Śniatkowski, Wydawnictwo Akademii Pedagogicznej, Kraków 1999.

Saloni Zygmunt, O kształceniu umiejętności pisania, Wydawnictwa Szkolne i Pedagogiczne, Warszawa 1979.

Słownik współczesnego języka polskiego, red. B. Dunaj, Wydawnictwo Wilga, Warszawa 1996.

Synowiec Helena, Język polski w szkole, w: Polszczyzna 2000. Orędzie o stanie języka na przełomie tysiąclecia, red. Walery Pisarek, Kraków 1999, s. 115-127.

Synowiec Helena, Kultura języka w polskiej szkole, w: Polszczyzna publiczna początków XXI wieku, red. Ewa Wolańska, Rada Języka Polskiego przy Prezydium PAN, Warszawa 2007, s. 28-48.

Synowiec Helena, O sytuacji języka ojczystego w zreformowanej szkole, w: Kompetencje nauczyciela polonisty we współczesnej szkole, red. Edyta Bańkowska, Agnieszka Mikołajczuk, Wydawnictwo Wydział Polonistyki UW, Warszawa 2006, s. 125-135.

Synowiec Helena, Śląska ojczyzna polszczyzna z perspektywy edukacyjnej. Wybrane zagadnienia, Wydawnictwo Sapientia, Katowice 2013.

Synowiec Helena, Zróżnicowanie terytorialne polszczyzny a edukacja językowa, w: Odmiany polszczyzny w szkole, red. Helena Synowiec przy współpracy Marty Kubarek, Wydawnictwo UŚ, Katowice 2013, s. 50-65.

Szymańska Marta, Między naukq o języku a rozwijaniem języka. Koncepcje kształcenia jezzykowego na przełomie XX i XXI wieku, Wydawnictwo Naukowe UP, Kraków 2016.

Teoretyczne, badawcze $i$ dydaktyczne założenia dialektologii, red. Sławomir Gala, Wydawnictwo Łódzkie Towarzystwo Naukowe, Łódź 1998.

Tokarski Jan, Gramatyka w szkole. Podstawowe zagadnienia metodyki, Państwowe Zakłady Wydawnictw Szkolnych, Warszawa 1966.

Tokarski Jan, Nauczanie gramatyki, w: Metodyka nauczania języka polskiego w klasach V-VIII szkoły podstawowej, red. M. Pęcherski, Warszawa 1970.

Tokarski Jan, Z pogranicza metodyki i językoznawstwa, Państwowe Zakłady Wydawnictw Szkolnych, Warszawa 1967.

W służbie nauce i szkole. Księga pamiątkowa poświęcona Profesorowi Doktorowi Zenonowi Klemensiewiczowi, komitet red. Wiesław Krencik (i in.), Państwowe Wydawnictwo Naukowe, Warszawa 1970. 
Wantuch Wiesława, Aspekty integracji w nauczaniu języka polskiego, Wydawnictwo Naukowe Akademii Pedagogicznej, Kraków 2005.

Wiazanie kształcenia językowego $z$ literackim $w$ gimnazjach $i$ liceach, red. Zenon Uryga, Ryszard Jedliński i Maria Sienko, Wydawnictwo Naukowe Akademii Pedagogicznej, Kraków 2007.

Wiedza o języku i kompetencje językowe uczniów, red. Bernadeta Niesporek-Szamburska, Wydawnictwo UŚ, Katowice 2012.

Wiedza o jezyku polskim w zreformowanej szkole, red. Agnieszka Mikołajczuk, Jadwiga Puzynina, Wydawnictwo Nowa Era, Warszawa 2004.

Wierzbiccy Anna, Piotr, Praktyczna stylistyka, Wiedza Powszechna, Warszawa 1968.

Wierzbicka Anna, Wierzbicki Piotr, Kształcenie sprawności językowej, w: Metodyka nauczania języka polskiego w kl. V-VIII, red. Mieczysław Pęcherski, Państwowe Zakłady Wydawnictw Szkolnych, Warszawa 1970.

Wierzbicki Piotr, Ćwiczenia stylistyczne, Wydawnictwa Szkolne i Pedagogiczne, Warszawa 1977.

Wiśniewska Halina, Sprawność językowa i komunikacyjna w historii dydaktyki polonistycznej (1950-2000), w: Kształcenie sprawności językowej. Obraz badań i dziatań dydaktycznych, red. Zenon Uryga, Maria Sienko, Wydawnictwo Naukowe Akademii Pedagogicznej, Kraków 2005.

Zbróg Piotr, Modele kształcenia językowego w podręcznikach do języka polskiego a potrzeby komunikacyjne uczniów, w: Podręczniki do kształcenia polonistycznego $w$ zreformowanej szkole - koncepcje, funkcje, język, red. Helena Synowiec, Wydawnictwo Edukacyjne, Kraków 2006, s. 29-42.

Zgółka Tadeusz, Zadania edukacyjne w zakresie kulturyjęzyka i etyki w szkole, w: Etyka Słowa. Wybór opracowań, red. Jerzy Bartmiński, Stanisława Niebrzegowska-Bartmińska, Jadwiga Puzynina, Wydawnictwo UMCS, Lublin 2017, s. 379-384. 


\title{
O funkcjonalności wiedzy o języku w szkole (na tle tradycji dydaktycznej)
}

\author{
Streszczenie
}

$\mathrm{W}$ artykule przypominam tradycje funkcjonalnego uczenia o języku w polskiej szkole, przywołując publikacje Zenona Klemensiewicza z lat międzywojennych oraz prace dydaktyków i językoznawców następnych pokoleń. Sygnalizuję przeobrażenia, jakie zachodziły w koncepcjach edukacji językowej pod wpływem rozwoju myśli pedagogicznej, psychologii, a przede wszystkim - subdyscyplin językoznawstwa. W nowym komunikacyjno-kulturowym modelu kształcenia nauka o języku zaczęła pełnić funkcję służebną. W tym kontekście dzielę się spostrzeżeniami dotyczącymi słabego poziomu wiedzy językowej absolwentów liceów (w tym studentów polonistyki). Koncentruję uwagę na zagadnieniach, jakie stoją przed dydaktykami języka polskiego, mającymi przygotować studentów filologii polskiej do zawodu nauczycielskiego. Wskazuję na konieczność uzupełnienia deficytów wiedzy lingwistycznej studentów, motywowania ich do pogłębiania znajomości systemu języka ojczystego i uzmysłowienia wielorakich jego wartości, „przełamywania” stereotypów, wyniesionych przez nich ze „szkolnego" kształcenia językowego, zaznajomienia ze strategiami uczenia o języku (i języka) w szkole, oraz z koncepcjami podręczników funkcjonalnie traktujących wiedzę o języku. Sygnalizuję swoiste problemy i potrzeby uczenia o odmianie ogólnej (standardowej) języka w środowiskach regionalnych, w których uczniowie przyswoili gwarę jako swój pierwszy kod językowy.

Słowa kluczowe: funkcjonalny, funkcjonalność, wiedza o języku, kształcenie językowe, dydaktyka nauki o języku 


\title{
On the functionality of knowledge about native language at school (the background of teaching tradition)
}

\author{
Summary
}

The present paper reminds us of the tradition of functional teaching about language in polish schools. This tradition goes back to the times between the two world wars. The changes which appeared in the concepts of language education at present are pointed out here. Due to these changes the knowledge about language was moved to the background and developing language and communicative abilities in the learners are moved to the foreground and emphasized. According to the author this policy resulted in the poor knowledge about native language represented by high school graduates who decided to study Polish language at the university.

The paper is also focused on the issues noticed by teacher trainers developing teacher professional abilities in the students of Polish language. The necessity of developing their knowledge of linguistics, motivating them to study the system of their native language, and also making them familiar with language learning and teaching strategies as well as with the concepts of preparing school coursebooks which include the functional knowledge about language is considered to be of crucial importance here.

The author also discusses the issue of presenting the knowledge about standard Polish to learners who acquired at first the regional variant of the language as their native language.

Keywords: functional, functionality, knowledge about language, teaching about language, language education

Helena Synowiec, prof., językoznawca, dydaktyk języka polskiego, pracownik Instytutu Językoznawstwa Uniwersytetu Śląskiego w Katowicach; zainteresowania badawcze: sprawność językowa dzieci i młodzieży oraz jej determinanty, kultura języka w szkole, funkcje, język i komunikatywność podręczników szkolnych, edukacja językowa i regionalna, dialekt śląski. Autorka i współautorka kilku monografii i licznych artykułów (m.in. Rozwój słownictwa nazywającego cechy osobowości w języku dzieci i młodzieży, Śląska ojczyzna polszczyzna z perspektywy edukacyjnej, Dziecko w świecie języka). Członek Rady Języka Polskiego przy Prezydium PAN i Komisji do Oceny Podręczników Szkolnych PAU. 